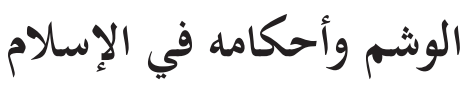

\title{
Islamic Ruling on Tattooing
}

\author{
Ahmed Mohammed Abdo Mohammed * \\ Ameen Ahmad Abdullah Qasem al-Nahari ** \\ Luqman Hj Abdullah ***
}

\begin{abstract}
Tattoos are an age-old phenomenon which has become ubiquitous in the modern age. This problem poses a challenge to the contemporary societies especially the Muslims, given the modern technology revolution, the influence exerted by western societies, and Muslims' ignorance of the Islamic Sharia Law. Therefore, this research aims to introduce the concept of the tattoo, describe its types, and explain the opinions of Fiqh scholars regarding the permissibility of a tattoo, and adapting such opinions to the contemporary lifestyles. This research makes use of the descriptive-inductive approach for the
\end{abstract}

* PhD Candidate, Department of Fiqh and Usul, Academy of Islamic Studies, University of Malaya, Alsharaabi2020@hotmail.com

** Senior Lecturer, Department of Fiqh and Usul, Academy of Islamic Studies, University of Malaya, alnahari1977@um.edu.my

*** Senior Lecturer, Department of Fiqh and Usul, Academy of Islamic Studies, University of Malaya, luqmanabdullah@um.edu.my 
purpose of reviewing and analyzing the opinions of Fiqh scholars in terms of tattoo types, the permitted (Halal) and prohibited (Haram) types, and the selection of more plausible opinions. This research has met with certain conclusions. Most importantly, it has been deduced that tattoos are divided into types; the first type is indelible (permanent) and cannot be removed except with extreme difficulty, and causing injury to the tattooed person. There are two sides to the The Figh opinion regarding this if the person knows the prohibition and is deliberately violating the rule, this is absolutely haram and the person is committing a sin; however, if the person is not deliberately violating the rule, this is permitted. The second type of tattoo is temporary and fades away naturally or by washing or medication without the tattooed person facing difficulties or sustaining injuries. This type is permitted unless it is harmful or uses material that prevents water from reaching the parts of ablution (Wudu').

Keywords: Tattooing, Islamic Ruling, Fiqh Scholar, Causing Harm

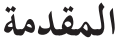

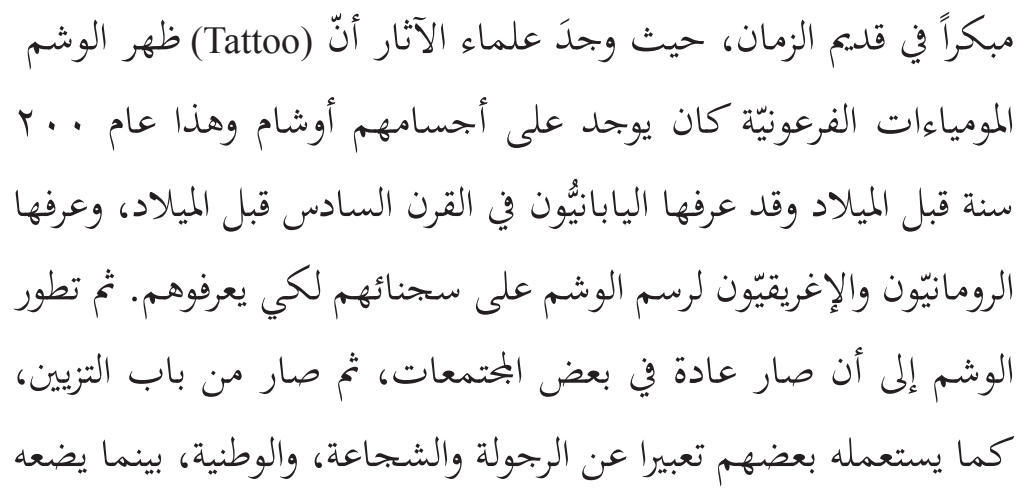


آخرون تقليدا أعمى، أو لإظهار انتماء ديني أو سياسي أو عرقي، وكل ذلك بحاجة إلى نظر وتمحيص من الناحية الشرعية بيانا لأقسامه وأحكامه.

ولقد اهتم علماء المسلمين بهذه الظاهرة ووضعوا أحكاما خاصة تتعلق كها، لما تشكله الأصباغ المستخدمة في الوشم بأشكاها وألواهما المختلفة

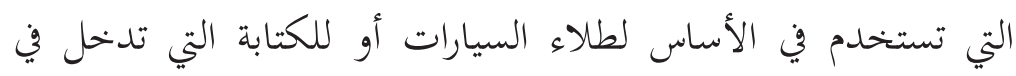

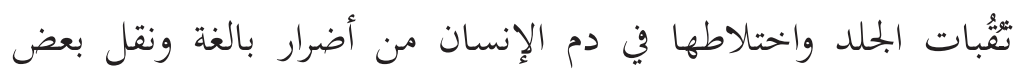

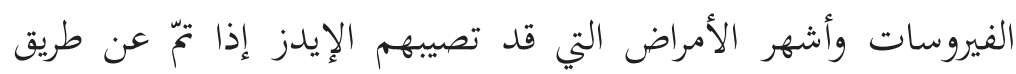

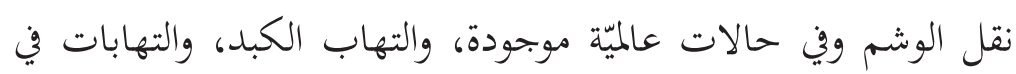
الجلد وأشهرها الإصابة بأمراض السرطانات الجلديّة وغيرها من الأمراض.

\section{تعريف الوشم والألفاظ ذات العلاقة به:}

الوشم لغة: العلامة، ويجمع على وشوم ووشائم , ووشم اليد وشما: غرزها

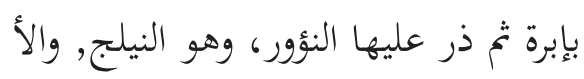

شم أيضا الوشم. واستوشمه: سأله أن يشمه. واستوشمت المرأة أرادت

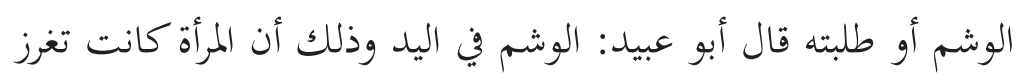

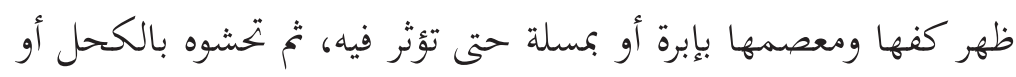

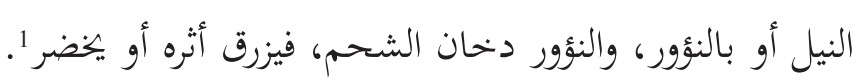

ومن معانيه أيضا: ما تراه من النبات في أول ما ينبت، وتغير لون الجلد

Ibn Manẓūr, Lisān al- 'Arab (al-Qāhirah: Dār Sādir, t.t), 12: 638. Ibrāhīm Muștafā, Aḥmad al-Zayyāt, Hamīd 'Abd al-Qādīr, alMu 'jam al-Wasìt (al-Iskandarīyah: Dār al-Da'wah, 1978), 2: 1035. 
من ضربة أو سقطة2.

واصطلاحا: هو غرز الجللد بإبرة حتى يخرج الدم، ثم يذر عليه نيلة أو كحل ليزرق أو يخضر

وتقيدهم باللون الأزرق والأخضر في التعريف ليس بقيد، وإنما هو باعتبار ما كان؛ بل يمكن التفنن فيه بأي لون؛ كما هو واقع الحال في زماننا، ومنها ألوان كثيرة حيث يتم فعلها على الجلد لرسم صور وأشكال تعبيريّة كالحيوانات والرسومات التشكيليّة أو كلمات تعبّر عن شخص معيّن، وهي طريقة يعتبرها البعض إظهارا لشخصيته.

وأما الوسم فهو في اللغة: أثر الكي، والعلامة، والجمع وسوم، وقد وسمه وسما وسمة: إذا أثز فيه بسمة وكي، ويف الحديث الصحيح الذي أخرجه البخاري (أنه (ص) كان يسم إبل الصدقة)4 أي يعلم عليها الكي، والسمة والوسام: ما وسم به البعير من ضروب الصور والميسم: الشيء الذي يوسم

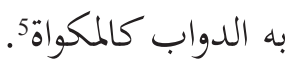

2 Ibid.

3 Muḥammad Amīn Ibn 'Umar Ibn 'Ābidīn, Radd al-Muḥtār 'alā alDurr al-Mukhtār (Bayrūt: Dār al-Fikr, 1992), 1: 330. Aḥmad Ibn Ghunāym Ibn Muhannā al-Nafrāwī, al-Fawākih al-Dawān̄i 'alā Risālah Ibn Ab̄̄ Zayd al-Qayrawān̄ì (Bayrūt, Lubnān: Dār al-Fikr, 1995) 2: 314. Abū Dāwud Sulaymān Ibn 'Umar Ibn Manșūr al'Ujaylī Jamal, Hāsyiyah al-Jamal 'alā Syarh al-Manhaj li Zakarīyā: al-Anșārī (Bayrūt: Dār al-Fikr, t.t), 1: 417.

4 Muḥammad Ibn Ismā’̄il al-Bukhārī, Șah̄ịh al-Bukhārī, Kitāb alZakāh, Bāb Wasm al-Imām Ibil al-Șadaqah Biyadihi, hadith no. 1502 (Bayrūt: Dār Ṭawq al-Najāh, 2001).

5 Ibn Manzūur, Lisān al- 'Arab, 12: 636. Ibrāhīm Mușțafā, Aḥmad alZayyāt, Hamīd 'Abd al-Qādīr, al-Mu'jam al-Wasìt, 2: 132. 
وفي الاصطلاح الوسم: العلامة بالنار أو بالشرط، والصلة بين الوشم

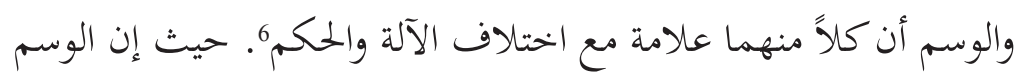
يكون بالحديد والنار، بينما الوشم يكون بغرز الابرة في جلد الإنسان. أما

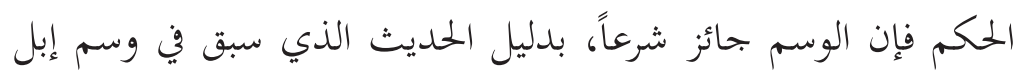

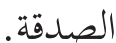

وأما الوشم فقد جاء تحريمه -لا بإطلاقه- على لسان حبيبه صلى الله عليه وسلم بذكر أحاديث كثيرة، كما سيأتي البيان عنها.

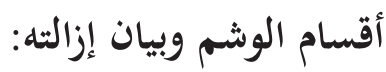

أن الوشم يختلف باختلاف نوعه وآلته ومدته، ولتحريم الوشم حكمة يظهر

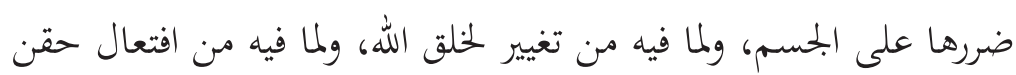

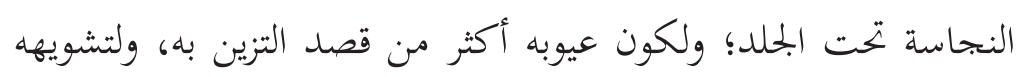

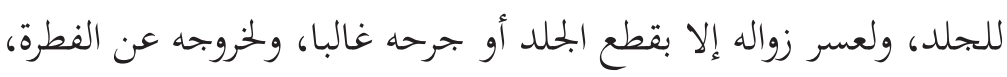
ولحيلولته عن وصول ماء الطهارة إلى الجسم عند إرادة تطهير العضو

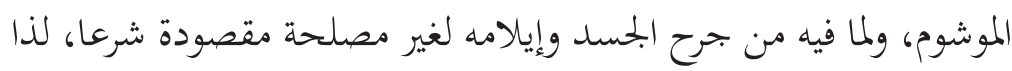

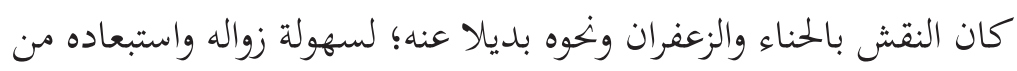

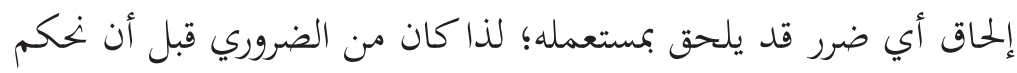
على الوشم لابد من معرفة أقسامه وشروطه ليتسنى بعد ذلك بيان الحكم بكم بكريم

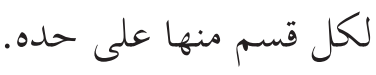

Zarūq Abū al-'Abās, Syarah Zarūq 'alā Matan al-Risālah li abī Zayd al-Q̄̄rāwan̄̄ (Bayrūt: Dār al-Kutub al-'Ilmiyyah, 2006) 2: 1098. 


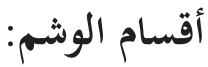

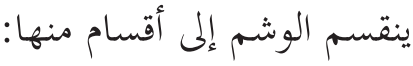

ا. أولا: الوشم المستحكم في الجلد: وهذا القسم نوعان: متعد به وغير

متعد به

منوع اتفاقاً: وهو ما كان سببه فعل فاعل فهو نوعان: مؤقت يمكن إزالته، ومستحكم في الجلد تعسر إزالته، والمستحكم الذي تعسر إزالته له حالتان: ما كان قبل البلوغ وما كان بعد البلوغ، كما سيأي بيانه في المبحث الرابع.

فأما ما كان بسبب الحوادث والجروح، وهو ما يحدث عادة بسبب تلوث الإصابة بالتراب أو العوالق التي تصبح جزءاً من الجرح أثناء الالتئام، مخلفة بذلك بقعاً ملونة مكان ندبة الجرح.

r. الوشم المؤقت: وهو الوشم السطحي الشائع في المتمعات الغربية والذي يعتمد فيه على الرسم والتلوين السطحي، فهو ليس وشماً بالمعنى المعروف، ولا يستلزم بحاسة إن لم تكن الأصباغ التي تستعمل له بخسة بذاتما8.

وهذا النوع لا يخلو من حالين: إما أن يكون مانعا من وصول الماء إلى

7 Aḥmad Ibn Aḥmad Ḥulwān̄̄, al-Wasm fi al-Wasym (al-Qāhirah: Muștafāà al-Bābī al-Ḥalabī, 1905), 28.

8 Muḥammad Sa 'īd Ramaḍān al-Būṭī, "al-Fatwa 25215,” Nasīm alSyām, retrieved 17 March 2016, http://www.naseemalsham.com/ar/ Pages.php?page $=$ readFatwa\&pg_id $=25215$ 
فإن كان يمنع من وصول الماء إلى البشرة فلا يخلو هذا المانع من حالين: إما أن يكون إزالته عسرة أو غير عسرة.

الحالة الأولى: أن تعسر إزالته من العضو المراد تطهيره، فيحرم فعله ابتداء؛ لما يترتب عليه من مفسدة في الدين وهي استحكام النجاسة في المكان الموشوم المنعقد من الدم المخلوط بالكحل ونخوه، أو منع وصول الماء إلى العضو المراد تطهيره.

الحالة الثانية: أن تكون إزالته غير عسرة: كأن يزول بنفسه أو بمجرد غسله وحكه أو بنحو صابون أو علاج دون أن يبقى أي أثر، وهذه الحالة لا إشكال فيها لزوال العلة المانعة المذكورة آنفا .. لكن اذا تعسرت إزالته بما ذكر وامكنت إزالته بالليزر من دون جرح ولا وجع تعين ذلك والله أعلمج. شروط استخدام الوشم المؤقت: كما أسلفنا سابقا أن الوشم أنواع، وقد تم بيان كل نوع، ومن هذه الأنواع الوشم المؤقت، ولجواز إباحته لابد أن تكون الإباحة مقيَّدة بشروط: أن يكون الرسم مؤقتاً يسهل إزالته بخلاف الثابت الدائم. أن يكون الرسم مؤقتاً يسهل إزالته بخلاف الثابت الدائم، وأن يتجرد عن رسومات ذوات الأرواح للنهي الشديد منها، وأن لا تظهر هذه الزينة لرجل أجنبي في حق المرأة، وأن لا يكون في تلك الألوان والأصباغ ضرر على الجلد ولو مستقبلاً. ومن الاضرار محظورات التيمم، وأن لا يكون فيها تشبه بالفساق Izdihār bintun Maḥmūd Ibn Șābir Madanī, Ahkām Tajmīl al-Nisā' fi al-Syarī 'ah al-Islāmīyyah (al-Riyāḍ: Dār al-Faḍīlah, 2002), 211. 
والكفار، وأن لا تحمل الرسومات شعارات تعظم ديناً محرَّاً، أو عقيدة

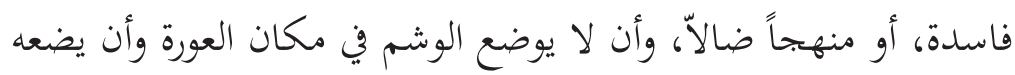
للرجل رجل مثله او امرأة محرم له ومثله في النساء عند امن الفتنة فإذا تيَّة هذا، فلا نرى مانع من التزين به، وأن لا يمنع وصول الماء إلى البشرة 10. آراء الفقهاء في حكم إزالة الوشم وأدلتهم: أباح الله تعالى لنا التزين بما أحله الله ورسوله، بشرط أن لا تكون رسومات على شكل ذوات الأرواح كإنسان أو حيوان، وبشرط أن لا تظهر هذه

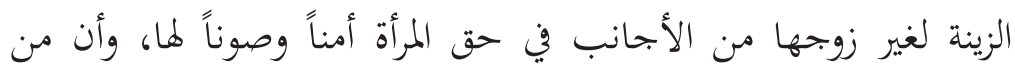

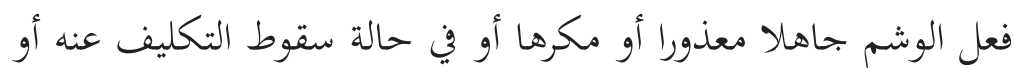
للحاجة المارة فصحيفته بيضاء من التعدي والحرمة فيعذر في إبقائه ولا

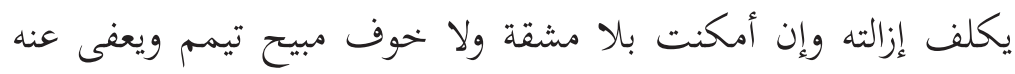

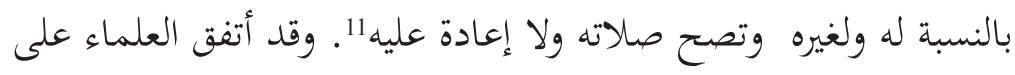

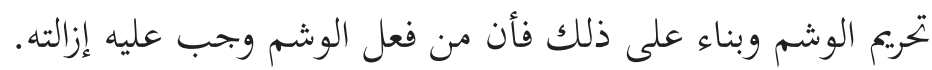
واختلفوا في إزالة الوشم حيث إنه بنس على النحو التالي: فذهب الحنفية: إلى أن حكم الوشم حكم الاختضاب أو الصبغ بالمتنجس

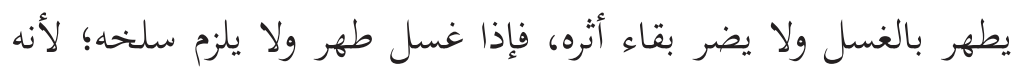

10 'Azifah al-Amal, "al-Akhțār al-Jasīmah allatī Yusabbibuhā alWasym wa al-Ḥikmah min Taḥrīmihā," Haqā'iq wa Iktishāfāt, retrieved on 6 February 2017, http://ttor2014.blogspot.my/2014/10/ blog-post_68.html.

11 Ibn 'Ābidīn, Rad al-Muhtāer 1: 330. 
وذهب المالكية إلى أن الوشم إذا وقع على الوجه الممنوع بأن لم يتعين دواء، ولم تتزين به الزوجة لزوجها، فإنه لا يكلف صاحبه بإزالته بالنار، بل هو من النجس المعفو عنه 13.

ويرى الشافعية: وجوب إزالة الوشم ما لم يخف ضررا يبيح التيمم¹4، فإن خاف لم يجب إزالته، ولا إثم عليه بعد التوبة، وهذا إذا فعله برضاه بعد بلوغه وإلا فلا تلزمه إزالته مطلقا، ولا ينجس ما وضع فيه يده إذا كان

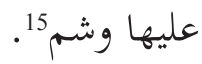

ويرى الحنابلة: إن خيط جرح أو جبر عظم من آدمي بخيط بخس أو عظم بنس فصح الجرح أو العظم لم بتجب إزالة النجس منهما مع خوف ضرر على نفس أو عضو أو حصول مرض؛ لأن حراسة النفس وأطرافها واجبة، وأهم من مراعاة شروط الصلاة، ولا يلزمه شراء ماء ولا سترة بزيادة كثيرة على ثمن مثله, وإذا جاز ترك شرط بحمع عليه لحفظ ماله، فترك شرط

12 Ibn 'Ābidīn, Rad al-Muhtāer, 1: 330.

13 Al-Nafrāwī, al-Fawākih al-Dawānī, 2: 314.

14 Aḥmad Ibn al-Husayn Abū Syujā' al-Ișfahānī, al-Ghāyah wa alTaqrīb (Damsyik: Dār al-Imān al-Bukhārī, 1978), 6.

15 Muḥammad Ibn Aḥmad al-Syirbīnī, Mughnī al-Muhtāj ilā Ma 'rifat Ma'ān̄̄ Alfāz al-Minhājj (Bayrūt: Dār al-Kutub al-'Ilmiyyah, 1994), 1: 406. Aḥmad Ibn Muḥammad Ibn Hajar al-Haytamī, 'Abd al-Ḥamīd Syirwān̄i; Aḥmad Ibn Qāsim al-'Abbādī, Hawāsȳ̄ al-Syirwān̄̄ wa Ibn Qāsim al-'Abbād̄̄ 'alā Tuhfat al-Muḥtāj (alQāhirah: al-Maktabah al-Tijāriyyah al-Kubrā, 1983), 2: 127. Muḥyi al-Dīn Yahyya Ibn Syaraf al-Nawawī, Rawḍatu al-Ṭālibīn (Bayrūt: Dār al-Ma'rifah, 2006), 1: 276. 
مختلف فيه لحفظ بدنه أولى، وحيث لم بحب إزالته فلا يتيمم للخيط أو

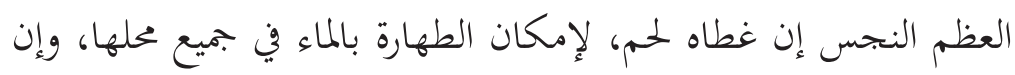

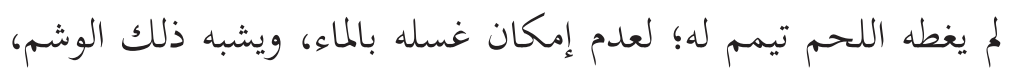
إن غطاه اللحم غسله بالماء، وإلا تيمم له، فلو مات من تلزمه إزالته لعدم

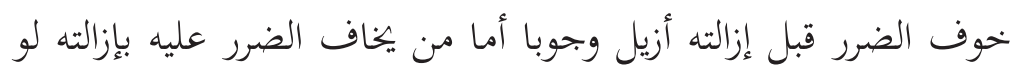
كان حيا فلا تلزم إزالته؛ لأنه يؤذي الميت ما يؤذي الحيكئ.

وجملة كلام الفقهاء على أن فعله يحرم ابتداء لغير حاجة معتبرة، ولا يُكلف في إزالته بعد فعله إن ترتب عليه مشقة واضحة يخشى معها ضرر مبيح لتيمه؛ للنصوص الواردة في ذلك، منها قوله تعالى:

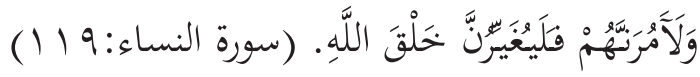

وقد ذكر الطبري عن الحسن البصري في معنى قوله تعالى 》افليغيرن خلق

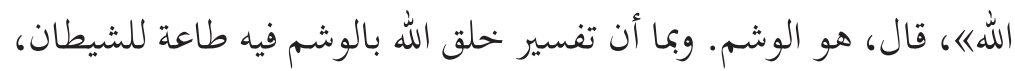
وقد هينا عن طاعته ينتج أن الوشم طاعة للشيطان وهي محرمة.

روى البخاري في الصحيح عن أبي جحفة (أن النبي ص فى عن ثمن

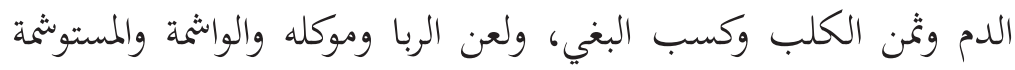

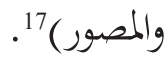

16 Mușțafā Ibn Sa $a$ d al-Suyūṭî, Mațālib ū $\bar{l}$ al-Nuhā fi Syarh Ghāyat alMuntahā (Bayrūt: al-Maktab al-Islāmī, t.t), 1: 364-365. Manșūr Ibn Yūnus al-Bahūtī, Kasȳf al-Qinā' 'an Matan al-Iqnā' (Bayrūt: Dār al-Kutub al-'Ilmiyyah, 1997) 1: 292.

17 Al-Bukhārī, Șaḥịh al-Bukhārī, Kitāb al-Libās, Bāb al-Wāsymah, hadith no. 5946. 
وفي هذا الحديث دلالة واضحة على أن النبي صلى الله عليه وسلم الوشمة ولا ينهى رسول الله صلى الله عليه وسلم إلا عن محرم أو مكروه إن صرفه الثه عن التحريم صارف ولا صارف هنا فينتج تحريم الوشم.

وقال ابن مسعود رضي الله عنه في قول الرسول صلى الله عليه وسلم (لعن

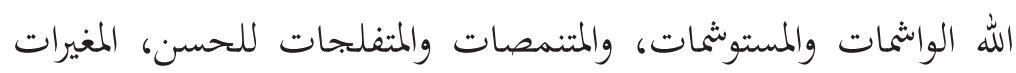

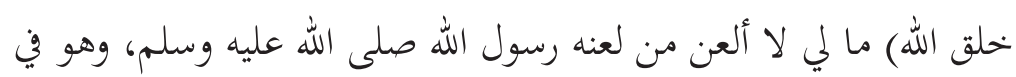

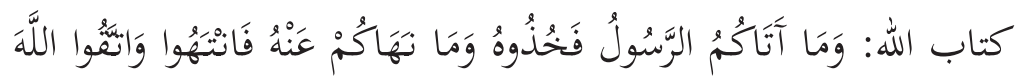

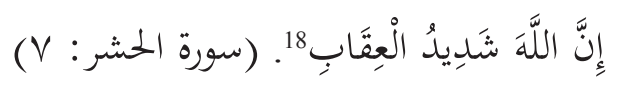

والمعروف من قواعد الشرع أن ما لعنه رسول الله من هذه الأشياء فهو من الكبائر، والوشم منها لأن رسول الله لعن فاعله.

ومعلوم أن النهي يفيد التحريم ما لم تصرفه قرينة ولا صارف هنا.

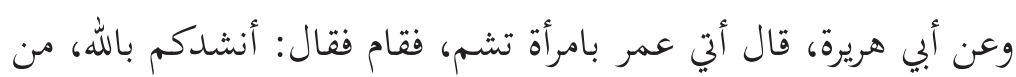

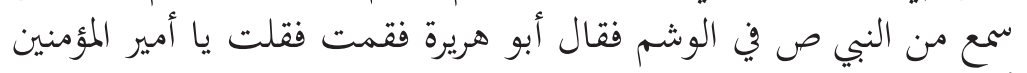

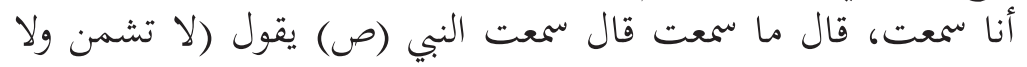
تستوشمن)

وهذا هي صريح من رسول الله صلى الله عليه وسلم عن الوشم فلايجوز تعديه.

18 Al-Bukhārī, Șaḥ̄ḥ al-Bukhārī, Kitāb al-Libās, Bāb al-Mawsūlah, hadith no. 5943.

19 Al-Bukhārī, Șaḥ̄ịhal-Bukhārī, Kitāb al-Libās, Bāb al-Mustawsyimah, hadith no. 5946. 
وعن ابن عباس رضي الله عنهما، قال رسول الله (ص) قال إبليس لربه:

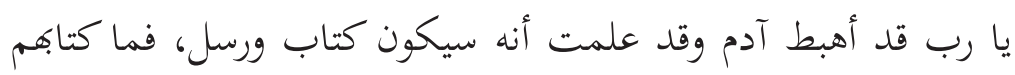
ورسلهم قال قال رسلهم الملائكة والنبيون منهم، وكتبهم التوراة والزبور

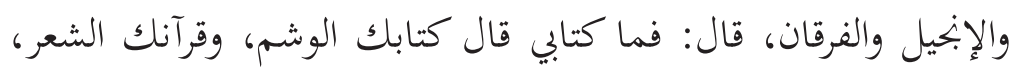

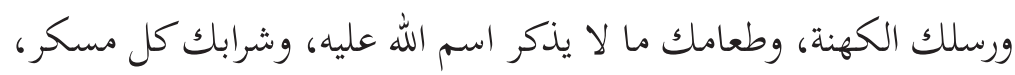

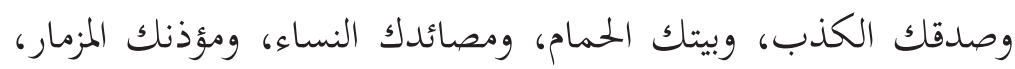

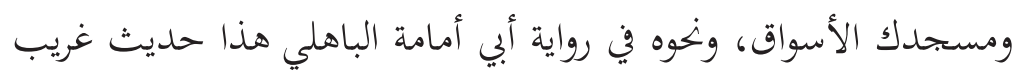

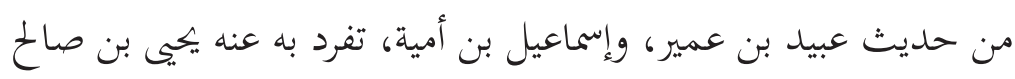
الأيلي من

فهذه الرواية تدل على أن الوشم من عمل ابليس الرجيم وقد غينا عن

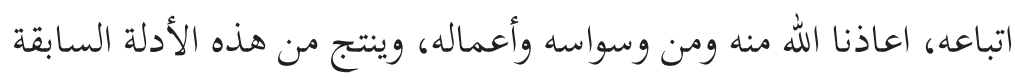

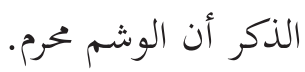
بل عده بعض المالكية والثافعية من الكبائر يلعن فاعله ${ }^{21}$. وقال بعض متأخري المالكية بالكراهة، قال النفراوي: ويمكن حملها على

20 Sulaymān Ibn Aḥmad al-Ṭabrān̄i, al-Mu ‘jam al-Kabīr (al-Qāhirah: Maktabah Ibn Taymiyyah, 1983) 11: 103. Aḥmad Ibn 'Abd Allāh Abū Nu'aīm al-Așfahānī, Hilyah al-Awliyā' wa Tabaqāt al-Asfiyā' (Miṣr: Dār al-Sa‘ādah, 1974), 3: 278.

21 Al-Nafrāwī, al-Fawākih al-Dawān̄̄, 2: 314. Aḥmad Ibn Muḥammad Ibn Ḥajar al-Haytamī, al-Zawājir 'an Iqtirāf al-Kabā' ir (Bayrūt: Dār al-Fikr, t.t), 1: 234. Muḥammad Ibn Aḥmad al-Dhahabī, Kitāb alKabā'ir (Bayrūt: Dār al-Nadwah al-Jadīdah, t.t), 165. 
التحريم22. أي كراهة تخريم ليتفق قول متأخري المالكية مع قول متقدميهم بالتحريم.

$$
\text { وقد استثنى النفراوي وغيره من الحرمة حالتين: }
$$

الأولى: الوشم إذا تعين طريقا للتداوي من مرض فإنه يجيوز؛ لأن الضرورات تبيح المخظورات.

الثانية: إذا كان الوشم طريقا تتزين به المرأة لزوجها بإذنه23، فقد روي (عن

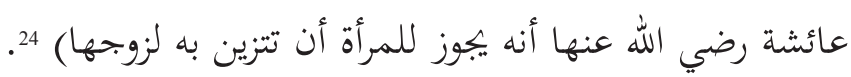

وهذا رأي له، والراجح ما ذهب اليه الجمهور، لضعف الأثر في ذلك.

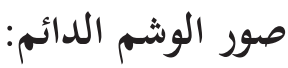

للوشم الدائم ثلاث صور بجملة وكلها لها نفس الحكم، وهو التحريم،

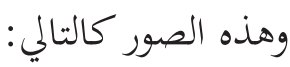

الأولى: الطريقة التقليدية القديمة، وهي ما ذكرنا سابقاً من غرز الإبرة بالجلد، وإسالة الدم، ثم حشي المكان كحلاً أو مادة صبغية.

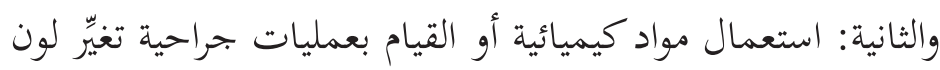

$\overline{22}$ Khāyr al-Dīn Ziriklī, al-A ' lām (Bayrūt: Dār al-'Ilm lil Malāyīn, 1990), 1: 192. Al-Nafrāwī, al-Fawākih al-Dawān̄̄ 'alā Risālah Ibn Abì Zayd al-Qayrawānī, 2: 314.

23 Al-Nafrāwī, al-Fawākih al-Dawānī, 2: 314. 'Alī Ibn Aḥmad 'Adawī, Hāsyiyah al- 'Adawì 'alā Syarh Kifâyah al-Ṭālib al-Rabbān̄i (Bayrūt: Dār al-Fikr, 1994), 2: 459.

24 Al-Nafrāwī, al-Fawākih al-Dawān̄i, 2: 314. 
والثالثة: طريقة الوشم المؤقت الذي قد تطول مدته إلى سنة25.

في ومحل الوشم غالباً في الوجه واليدين، وفي الشفة، ثم إن الناس يتفننون

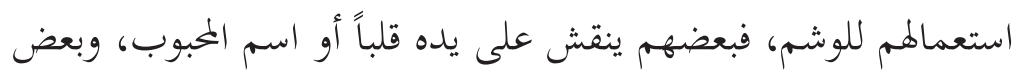

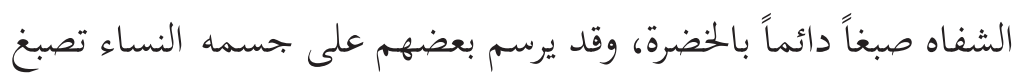
ونخو ذلك. قال ابن حجر 26: اوذكر الوجه صورة حيوان كأسد أو عصفور في للغالب وأكثر ما يكون في الشفة وذكر الوجه ليس قيدا وقد يكون

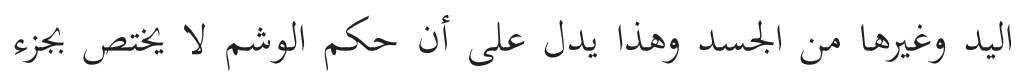

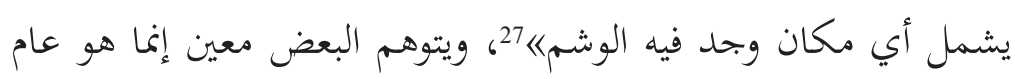

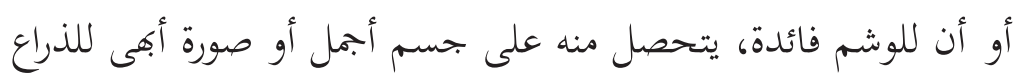

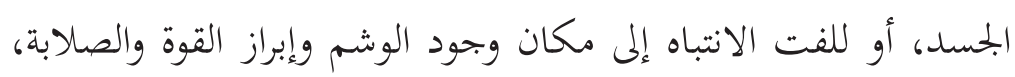

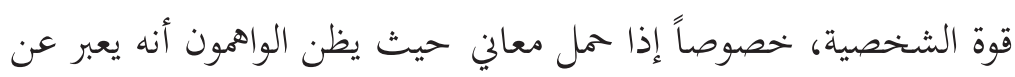

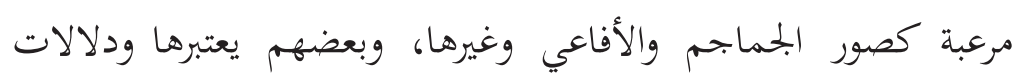

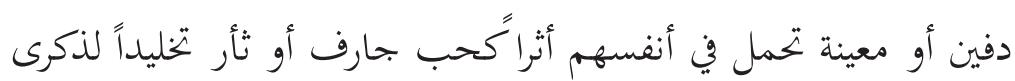
عرفان بجميل لشخص معين، وذلك بتحميل بعض الرسوم كتابات معينة

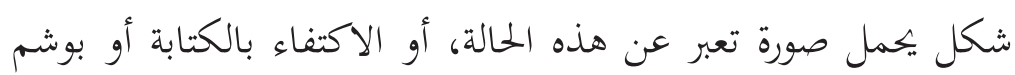
والحقيقة أن الوشم هو نوع من الاختلال النفسي وتقليد لنجوم الأغنية

25 "Al-'Ilm Yathbut Ḥikmah Taḥrīm al-Wasym al-Dāim 'alā al-Jasad", Syabkah al-'Ilām al-'Arabiyah, retrieved 12 March 2016, http:// www.moheet.com/2013/03/11/1739236.

26 Al-Dīn Ziriklī, al-A 'lām, 1: 178.

27 Aḥmad Ibn 'Alī Ibn Ḥajar al-'Asqalānī, Fath al-Bārì bi Syarh Ṣaḥịh al-Bukhārī (Bayrūt: Dār al-Ma'rifah, 1959), 10: 372. 
الشاشات التلفزيونية بصورة أبطال وبكوم، فيأتي منا الصاخبة ممن تظهرهم التقليد لتلك الأمثلة دون التفكير في معاني ما يحملون على أجسادهم، شخصية الموشوم بتعله كما أها تعبر عند البعض عن تغيرات تطرأ على الترهات يأتي على هذا النوع للتعبير عن نفسيته وتميزه في البحتمع وكل تلك

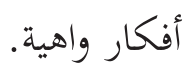

ولعل من أجحاز الوشم استدل بهذا الحديث عن قيس بن أبي حازم، قال: ادخلنا على أبي بكر رضي الله عنه في مرضه فرأينا امرأة بيضاء موشومة اليدين تذب عنه وهي أسماء بنت عميس 28) وقد صححه الحافظ في فتح الباريج26، إضافة لتعارضه مع الأحاديث الصحيحة المصرحة بالحرمة، ولعل الحديث إن صح محمول على الخضاب والحناء أو التدواي كما سبق بيانه، أو كان فعلها قبل النهي فتعسرت إزالته فاستمر في يدهات3. القواعد الفقهية المتعلقة بالوشم: إذا تأملنا قواعد الفقهاء بندها تشير إلى تحيم الوشم ومن القواعد الواضحة

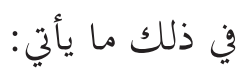

28 Al-Ṭabrānī, al-Mu jam al-Kabīr, 24:131. Aḥmad Ibn Muḥammad alKhallāl, Kitāb al-Sunnah (al-Riyāọ: Dār al-Rāyah, 1989), 1:267.

29 Ibn Ḥajar al-'Asqalānī, Fath al-Bārī bi Syarḥ Ṣaḥ̄ḥ al-Bukhārī, 10:376.

30 Aḥmad Ibn Muḥammad Qasțallānī, Irsyād al-Sārī li Syarḥ Șaḥ̄ḥ al-Bukhārī (Miṣr: Būlāq: Maṭba'ah al-Kubrā al-Amīriyyah, 1905), 8:467. 'Alī ibn Khalaf Ibn Baț̣āal, Syarh Ibn Batțāl 'alā Șah̄ịh alBukhārī (al-Riyāḍ: Maktabah al-Rusyd, 2003), 9:169. 


$$
\text { القاعدة الأولى: (لا ضر ولا ضرار) }
$$

إستنبط الفقهاء هذه القاعدة من ادلة عدة مثل قوله تعالى:

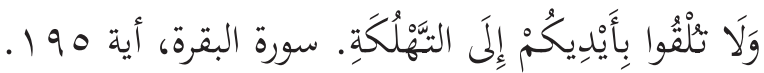

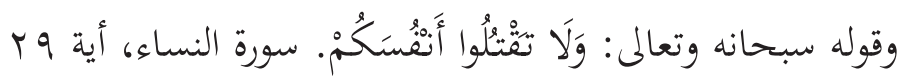

ومن الأحاديث قول النبي صلى الله عليه وسلم 》الا ضرر ولا ضراري32 لأن الاسلام حريص على صحة الإنسان ليتمكن من عبادة الله وإقامة شرعه وكل ما يعرض الإنسان للأمراض والأضرار فهو منهي عنه والوشم فيه ضرر وضح على جسم الإنسان من ثقب للبدن ومن وضع الكحل والمواد التي تضر بالبدن فلهذا لا يجوز •

القاعدة الثانية: (وجوب العمل بقول أهل الخبرة عند الحاجة الم قولهم)33. لقد ثبت عن أهل الخبرة في الطب كما سلف. أن الوشم يسبب بعض الأمراض مثل سرطان الجلد والحساسية والتسمم الجلدي، لما فيه من مضرة جسيمة على الإنسان، وقد عضد قولمم أدلة الشرع الصريمة في النهي عن الوشم وبهذا يتضح أو يستفاد هنا تحيم الوشم طبا وشرعا. فظهر محا سبق تحريم الوشم وجواز إزالته بالشروط السابقة ذكرها، لقوة الدليل وانسجاما مع القواعد الفقهية السابقة ذكرها، ويضاف إضافة إلى

31 Abū Ya'lā Muhammad Ibn al-Ḥusayn Ibn al-Farrā', al- 'Uddah fi 'Usul al-Figh (al-Riyāḍ: al-Mamlakah al-'Arabiyah al-Sa'ūdiyah, 1993), 5: 1522.

32 Ibn Majāh, Sunan Ibn Mājah, Kitāb al-Ahkām, Bāb Man Banā fī Haqqihi Mā Yadurr Bijārihi, hadith no. 2340, ed. Muhammad Fuad 'Abd al-Bāqī (t.tp: Dār Iḥyā’ al-Kutub al-'Arabiyyah, t.t), 784.

33 Jalāl al-Dīn 'Abd al-Raḥmān Ibn Abī Bakar al-Suyūṭī, al-Asybāh wa al-Nază 'ir (Bayrūt: Dār al-Kutub al-'Ilmiyyah, 1990), 1: 75, 392, 485 . 
قول أهل الخبرة والإختصاص من الأطباء فيما يتعلق بإصابة الجلد من

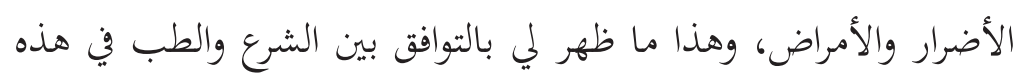
المسألة.

\section{الخلاصة}

ذهب جمهور الفقهاء أن فعل الوشم حرام آتم فاعله للنصوص الصحيحة الواردة في تحريمه، وحملوها على الوشم المستحكم على الجلد. وئم ويرى اهل الهل

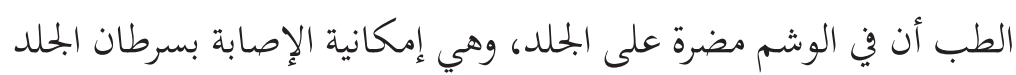

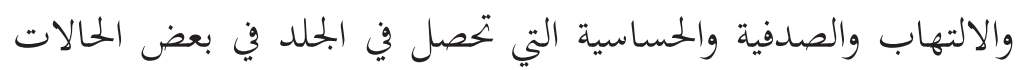

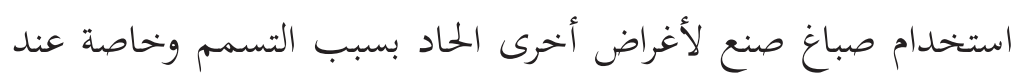
كطلاء السيارات أو حبر الكتابة، وسوء التعقيم الذي يؤدي إلى انتقال

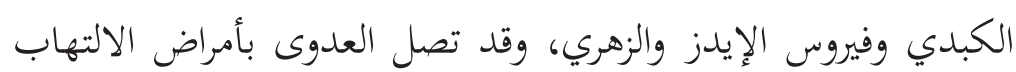

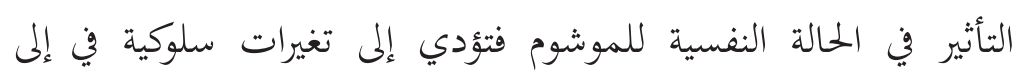

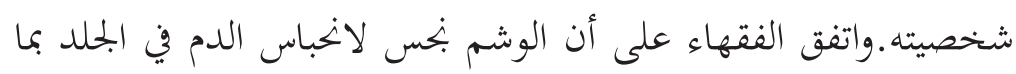

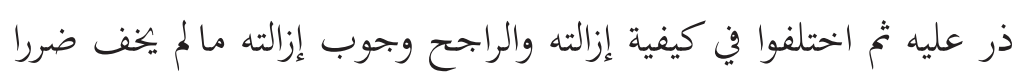

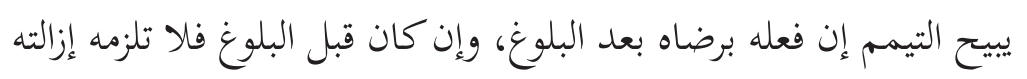

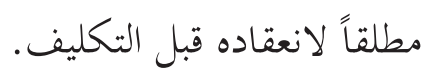




\section{BIBLIOGRAPHY}

Abū Dāwud Sulaymān Ibn 'Umar Ibn Manșūr al-'Ujaylī Jamal. Hāsyiyah al-Jamal 'alā Syarh al-Manhaj li Zakarīyā: alAnșārī. Bayrūt: Dār al-Fikr, t.t.

Abū Ya'lā Muḥammad Ibn al-Ḥusayn Ibn al-Farrā'. Al- 'Uddah fi 'Ușūl al-Fiqh. Al-Riyāḍ: al-Mamlakah al-'Arabiyah alSa'ūdiyah, 1993.

Aḥmad Ibn Aḥmad Ḥulwānī. Al-Wasm fi al-Wasym. Al-Qāhirah: Muștafā al-Bābī al-Ḥalabīi, 1905.

Aḥmad Ibn Muḥammad Qasțallānī. Irsyād al-Sārì li Syarḥ Șaḥ̄h al-Bukhārì. Mișr: Būlāq: Maṭba'ah al-Kubrā al-Amīriyyah, 1905.

'Alī Ibn Khalaf Ibn Batțāl. Syarh Ibn Bațtāl 'alā Saḥ̄ḥ al-Bukhārī. al-Riyāḍ: Maktabah al-Rusyd, 2003.

Al-'Adawī, 'Alī Ibn Aḥmad. Hāsyiyah al-'Adawī 'ala Syarh Kifāyah al-Tālib al-Rabbān̄i. Bayrūt: Dār al-Fikr, 1994.

Al-Amal, 'Azifah. "Al-Akhtār al-Jasīmah allatī Yusabbibuhā alWasym wa al-Ḥikmah min Tahrīmihā," Haqāiq wa Iktishfāt, accessed on 6 February 2017, http://ttor2014.blogspot. my/2014/10/blog-post_68.html.

Al-Aṣfahānī, Aḥmad Ibn 'Abdullāh Abū Nu'aīm. Hilyah alAwliyā' wa Ṭabaqāt al-Assfiyā'. Mișr: Dār al-Sa'ādah, 1974.

Al-'Asqalān̄̄, Aḥmad Ibn 'Alī Ibn Hajar. Fatḥ al-Bārì bi Syarḥ Saḥ̄h al-Bukhārì. Bayrūt: Dār al-Ma'rifah, 1959.

Al-Bahūtī, Manșūr Ibn Yūnus. Kasyf al-Qinā' 'an Matan al-Iqnā' . Bayrūt: Dār al-Kutub al-'Ilmiyyah, 1997.

Al-Bukh̄ārī, Muḥammad Ibn Ismā'îl. Șaḥịh Al-Bukh̄ārī. Bayrūt: Dār Ṭawq al-Najāh, 2001.

Al-Būṭī, Muḥammad Sa'īd Ramaḍān. "al-Fatwa 25215," Nasìm alSyām, retrieved 17 March 2016, http://www.naseemalsham. com/ar/Pages.php?page=readFatwa\&pg_id $=25215$ 
Al-Dhahabī, Muḥammad Ibn Aḥmad. Kitāb al-Kabā'ir. Bayrūt: Dār al-Nadwah al-Jadīdah, t.t.

Al-Haytamī, Aḥmad Ibn Muḥammad Ibn Hajar, 'Abd al-Hamīd Syirwān̄̄, Aḥmad Ibn Qāsim al-'Abbādī. Hawāsȳ̄ alSyirwān̄̄ wa Ibn Qāsim al- 'Abbāō̄ 'alā Tuhfat al-muhtā̄j. al-Qāhirah: al-Maktabah al-Tijāriyah al-Kubrā, 1983.

Al-Haytamī, Aḥmad Ibn Muḥammad Ibn Hajar. Al-Zawājir 'an Iqtirāf al-Kabā'ir. Bayrūt: Dār al-Fikr, t.t.

"Al-'Ilm Yathbut Ḥikmah Taḥrīm al-Wasym al-Dāim 'alā alJasad." Syabkah al-'Ilām al-'Arabiyah, accessed on 12 March 2016, http://www.moheet.com/2013/03/11/1739236.

Al-Iṣfahānī, Aḥmad Ibn al-Ḥusayn Abū Syujā'. Al-Ghāyah wa alTaqrīb. Damsyik: Dār al-Imān al-Bukhārī, 1978.

Al-Khallāl, Aḥmad Ibn Muḥammad. Kitāb al-Sunnah. al-Riyāẹ: Dār al-Rāyah, 1989.

Al-Nafrāwī, Aḥmad Ibn Ghunāym Ibn Muhannā. Al-Fawākih alDawān̄̄ 'alā Risālah Ibn Ab̄̄ Zayd al-Qayrawānī. Bayrūt, Lubnān: Dār al-Fikr, 1995.

Al-Nawawī, Muḥy al-Dīn Yahyya Ibn Syaraf. Rawdatu al-Ṭālibìn. Bayrūt: Dār al-Ma'rifah, 2006.

Al- Suyūṭ̣̂, Jalāl al-Dīn 'Abd al-Raḥmān Ibn Abī Bakar. Al-Asybāh wa al-Naz̄ā'ir. Beirūt: Dār al-Kutub al-'Ilmiyyah, 1990.

Al-Suyūṭ̂, Muștafā Ibn Sa'd. Matāilib ūtī al-Nuhá fi Syarḥ Ghāyat al-Muntahā. Bayrūt: al-Maktab al-Islāmī, t.t.

Al-Syirbīn̄̄, Muḥammad Ibn Aḥmad. Mughn̄i al-Muḥtāj ilā Ma 'rifat Ma 'ānī Alfāz al-Minhāj. Bayrūt: Dār al-Kutub al'Ilmiyyah, 1994.

Al-Ṭabrān̄̄, Sulaymān Ibn Aḥmad. Al-Mu jam al-Kabīr. alQāhirah: Maktabah Ibn Taymiyyah, 1983.

Ibn Manẓūr. Lisān al- 'Arab. al-Qāhirah: Dār Sādir, t.t.

Ibrāhīm Muștafā, Aḥmad al-Zayyāt, Hamed 'Abd al-Qādīr. Al- 
Mu 'jam al-Wasīt. al-Iskandarīyah: Dār al-Da‘wah, 1978.

Ibn Mājah. Sunan Ibn Mājah. Ed. Muhammad Fuad 'Abd al-Bāqī. T.tp: Dār Iḥyā’ al-Kutub al-'Arabiyyah, t.t.

Izdihār bintun Mạ̣mūd Ibn Șābir Madanī. Ahkām Tajmīl al-Nisā' fi al-Syarì 'ah al-Islāmīyyah. al-Riyāḍ: Dār al-Faḍilah, 2002.

Khāyr al-Dīn Ziriklī. Al-A 'lām. Bayrūt: Dār al-'Ilm lil Malāyīn, 1990.

Muḥammad Amīn Ibn 'Umar Ibn 'Ābidīn. Rad al-Muḥtār 'alā alDurr al-Mukhtār. Bayrūt: Dār al-Fikr, 1992. 